\title{
Modeling spatio-temporal shoreline and areal dynamics of coastal island using geospatial technique
}

\author{
Al Emran ${ }^{1}$ (D) Md. Abdur Rob ${ }^{1} \cdot$ Md. Humayun Kabir ${ }^{1}$ Md. Nazrul Islam²
}

Received: 8 November 2015/ Accepted: 23 November 2015/Published online: 14 December 2015

(C) Springer International Publishing Switzerland 2015

\begin{abstract}
This study aimed at assessing the changes in the shoreline and the area of Sandwip Island, Bangladesh using multi-temporal satellite image and geospatial techniques. The study results (1980-2014) indicate that the island has gained approximately $25 \mathrm{~km}^{2}$ land areas and has lost about $64 \mathrm{~km}^{2}$ of its original land area during this time. The net loss of the shore-length was approximately $3.1 \mathrm{~km}$ or $0.1 \mathrm{~km} /$ year and the net loss of $38.84 \mathrm{~km}^{2}$ or $1.14 \mathrm{~km}^{2} /$ year areas. The erosion process has been taken place along the western, south-western, and southern banks of the island. In these areas, the landward movement and rate of the shoreline were higher with a highest value of the net shoreline movement (NSM) around $3.8 \mathrm{~km}$ and the end point rate (EPR) more than $100 \mathrm{~m} / \mathrm{year}$ in some parts. The accretion, on the other hand, has been taken place along the northern and north-eastern banks of the island at relatively slower rates with the NSM $<2.8 \mathrm{~km}$ and the EPR $<100 \mathrm{~m} /$ year.
\end{abstract}

Keywords Coast - Shoreline - Geospatial technique . Change detection $\cdot$ Erosion-accretion

Al Emran

al.emran@yahoo.com

1 Department of Geography and Environment, University of Dhaka, Dhaka, Bangladesh

2 Department of Geography and Environment, Jahangirnagar University, Savar, Dhaka, Bangladesh

\section{Introduction}

The coast is a unique arena of great importance because a large number of people inhabit in these areas. It is the most dynamic and energetic environment on the earth which is exposed to a series of dynamic natural processes e.g. coastal erosion, sediment transport, coastal development etc., causing changes in various time spans (Bouchahma and Yan 2012). Sea level rise (SLR) has a direct role in erosion of the coastal areas (Mukhopadhyay et al. 2011) as the already developed models confirm the impacts of sea level rise on coastal modification and erosion process (Brunn 1962; Dean 1977; Everts 1985). SLR can result the disappearance of up to $22 \%$ of coastal wetlands of the world by the 2080s (Nicholls et al. 1999) and it may up to $70 \%$ if other loss works together (Sarwar 2005). This rise of sea level reflects its impacts in different forms such as erosion of islands and shores and the deluge of low-lying lands (Healy 1991). The erosion occurs as the increasing water level results in enduring or permanent loss of materials from the shore thereby affecting the sediment reservoirs from the shore (Mukhopadhyay et al. 2011). It poses an immense vulnerability to the nearly $10 \%$ of coastal human communities of the world lies within an elevation of $10 \mathrm{~m}$ from mean sea level (MSL) (McGranahan et al. 2007) due to the shoreline shifting coupling with coastal erosion. Albeit the impacts are spatially uneven, the developing countries are likely to be worst affected (Nicholls et al. 2007; Dasgupta et al. 2009). The issue of shoreline changes, thus, has increasingly been a major social, economic and environmental concern to many countries along the coast (Chand and Acharya 2010).

Bangladesh is recognized for its high vulnerability to sea level rise (Brammer et al. 1993) with its $10 \%$ of the land area hardly $1 \mathrm{~m}$ above the mean sea level and one-third 
under tidal excursions (Sharmin 2013). The World Bank (2000) showed that a $10 \mathrm{~cm}, 25 \mathrm{~cm}$ and a $1 \mathrm{~m}$ rise in sea level by 2020, 2050 and 2100 will affect 2, 4 and $17.5 \%$ of total land area of the country respectively. It has already affected through land erosion, salinity intrusion and biodiversity loss (Sarwar 2005). The UNEP ${ }^{1}$ (1989) reported that a $1.5 \mathrm{~m}$ sea level rise will affect about $22,000 \mathrm{~km}^{2}$ (16\% of total land mass) with a population of 17 million ( $15 \%$ of total population) by 2030. About 2500,8000 and $14,000 \mathrm{~km}^{2}$ of land (with a corresponding 2, 5 and $10 \%$ of the total land area) will be lost due to a rise of $0.1,0.3$ and $1.0 \mathrm{~m}$ respectively (Ali 2000). SLR accelerates erosion processes, washes out the loose materials of the coast and makes the coastal regions to be steeper through raising the water level (Sarwar 2005). The country's most vulnerable shore types to sea level rise are shoaly, sandy and silty shores (Kont et al. 1997) which undergo easily to be eroded. Moreover, sea level rise can alter the morphological behavior of the river through increasing river discharge that further accelerates river bank erosion (Alam 2003). About $196 \mathrm{~km}^{2}$ of the island $(\text { char })^{2}$ has eroded and a total of 11 offshore islands have disappeared from the Meghna Estuary between 1972 and 1987 (Pramanik 1988; Cited in SDNP 2004). Sandwip, an offshore island in the Bay of Bengal, has significantly reduced in size during the past 200 years. In 1780, it had a total area of about $480 \mathrm{~km}^{2}$ and increased to $502 \mathrm{~km}^{2}$ in 1880 whereas in 1979 it was reduced to $290 \mathrm{~km}^{2}$ only (Rob 1997). The island was reduced to about $50 \%$ of its original size with substantial erosion in the northwest and accretion in the southeast during the past 75 years (1913-1988). The erosion on the northwest coast accelerated after 1963 and it was about $200 \mathrm{~m} /$ year between 1913 and 1963 and was about $350 \mathrm{~m} /$ year between 1963 and 1984. About $40 \%$ of the island in the east was eroded between 1984 and 2007 (Brammer 2014).

The accurate mapping of the shoreline and coastal changes are very important for adopting conservation measures e.g. protection of human life, property and the natural environment (Tirkey et al. 2005). The analysis of shoreline change and coastal area demands utilizing information on natural processes i.e. shoreline erosionaccretion. Monitoring shoreline change needs a long-term commitment based on the temporal change modeling using remote sensing (RS)-geographic information system (GIS) database (Bouchahma and Yan 2012). Thus, information about the coastline and its modification over time is essentially needed for the management of coastal zones and its environmental issues (Wang et al. 2013). Remote-sensing satellite images are used to dynamically

\footnotetext{
${ }^{1}$ United Nations Environment Programme.

2 The Bengali meaning of island(s).
}

monitor the coastline change in effective means (Wang et al. 2013) with the integration of GIS techniques (Yanli 2011). Remote sensing is the most advantageous method for different change detection studies (Behera et al. 2012; Bortels et al. 2011) because of its low-cost and reliable information source with high-frequency and repeatable observations. Spectral water index methods can extract water body information more accurately, quickly and easily than others general methods ( $\mathrm{Li}$ et al. 2013). Water indices are mathematical models to enhance the water signals for a given pixel at images (El-Asmar and Hereher 2010) which are applied for change detection of water body information and for the shoreline studies of the coastal areas. The most used water indices are the normalized difference water index (NDWI) (McFeeters 1996) and the modified normalized difference water index (MNDWI) (Xu 2006). These indices use the reflection of the green, near-infrared, mid-infrared and short-infrared spectra (McFeeters 1996; Xu 2006; Li et al. 2013). The reason for selecting these wavelengths is to maximize the reflectance properties of water using green wavelengths, to minimize the low reflectance of NIR/MIR/SWIR by water features and to maximize the high reflectance of NIR/MIR/SWIR by terrestrial vegetation and soil features (McFeeters 1996; Xu 2006; Li et al. 2013). The temporal shoreline data can be useful to detect the predominant coastal processes operating in specific locations using change rates as an indicator of shoreline dynamics (Chand and Acharya 2010).

The objectives of the present study are to use remote sensing and GIS to evaluate spatial and temporal changes in the shoreline and coastal land area of the Sandwip Island between the year of 1980 and 2014 i.e. assessing shifting of the shoreline position through digital shoreline analysis besides the erosion-accretion measurements.

\section{Study area}

The study area is located in the Chittagong District of the Bangladesh, between the $22^{\circ} 22^{\prime} \mathrm{N}$ to $22^{\circ} 34^{\prime} \mathrm{N}$ latitude and $91^{\circ} 26^{\prime}$ to $91^{\circ} 34^{\prime} \mathrm{E}$ longitude. The island is surrounded by Bamni River in the north, Meghna River and Hatia Island in the west, Sandwip Channel and Sitakundo Upazilla ${ }^{3}$ in the east and the Bay of Bengal in the south (Fig. 1). According to the government official statistics (BBS 2014), near about 400,000 people live in there. The size of the island is changing due to bank erosion in the sea. Formed by silt deposits from the Meghna Estuary, the exceptionally fertile area of the island is, however, being continually subjected to changes.

\footnotetext{
${ }^{3}$ An administrative sub-unit of districts.
} 


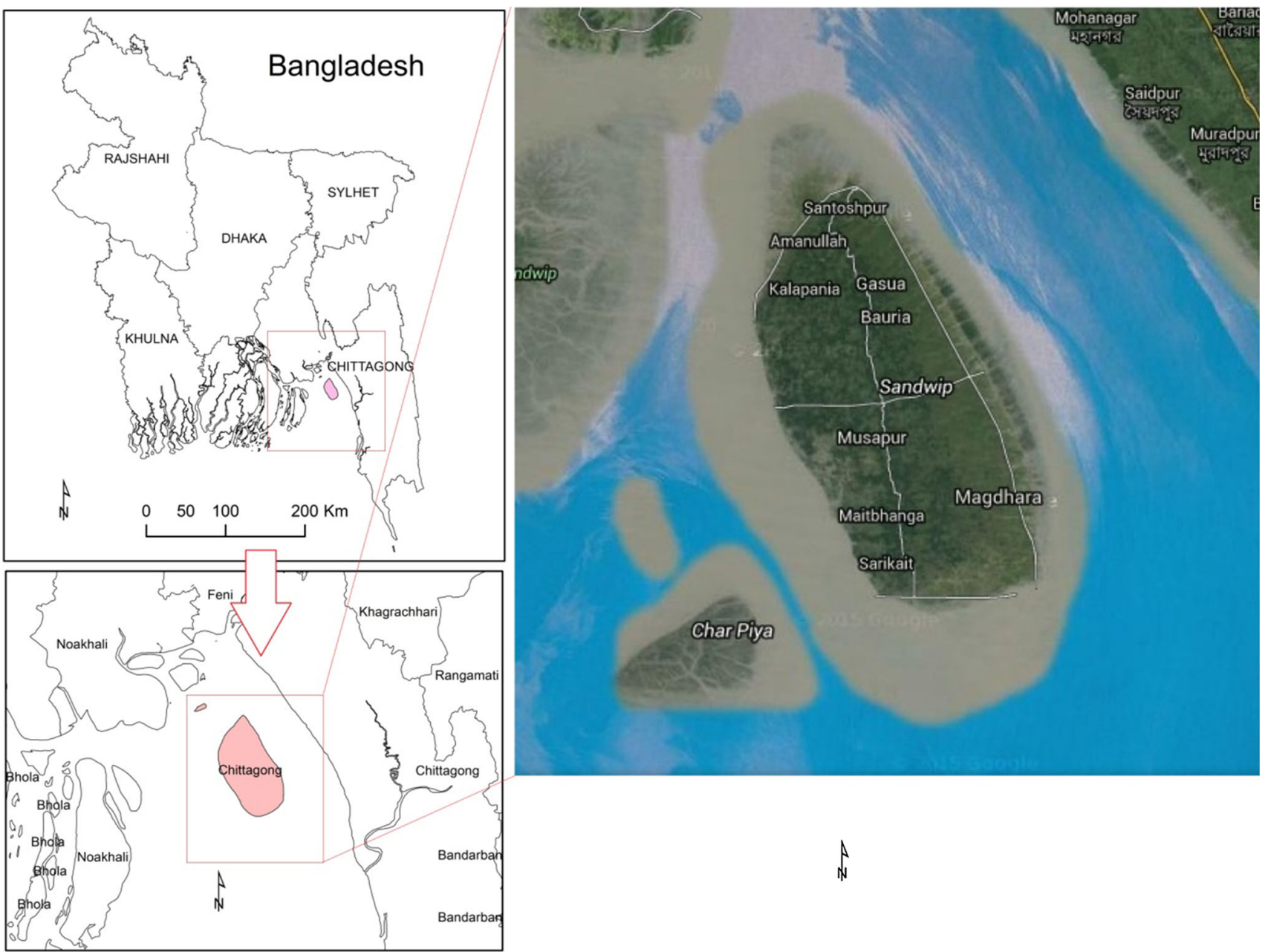

Fig. 1 Location of the study area (Source: Google Earth, 2014)

\section{Materials and methods}

\section{Satellite data}

The study has used Landsat satellite images from the year of 1980 to 2014, downloaded from the USGS-Glovis and Earth Explorer website. The images were selected considering the cloud cover, visibility of the scene, satellite image quality and availability of the MSS, TM, ETM+ and OLI-TIRS sensor satellite data (Fig. 2). Moreover, all the images were taken in the dry season (between the months of December-April) to minimize the seasonal effects. The image data used in the study are described in Table 1.

\section{Image processing}

The images used in the present study are the level-1 products of the USGS that were referenced in the World Geodetic System (WGS84) datum and projected using the Universal Transverse Mercator system (zone UTM 46 North) in
GeoTiff format. The McFeeters's NDWI and Xu's NDWI can conveniently be extracted from top-of-atmosphere (TOA) reflectance rather than the raw quantized calibrated pixel value (DN) ( $\mathrm{Li}$ et al. 2013). Using TOA reflectance over at-sensor spectral radiance is more advantageous when comparing images from different sensors because it efficiently removes the cosine effect at different solar zenith angles arising from the temporal variation between data sets, compensates for different values of the exo-atmospheric solar irradiance arising from spectral band differences and corrects for the variation in the earth-sun-distance for different data acquisition dates (Karsli et al. 2011; Chander et al. 2009; Li et al. 2013). Therefore, in the present study, the TOA reflectance of the MSS, TM, ETM+ and OLI data were used. The TOA reflectance can be calculated from the DN value, as given by (Chander et al. 2009):

$\mathrm{P}_{\lambda}=\pi * L_{\lambda} * d^{2} / \operatorname{ESUN}_{\lambda} * \operatorname{Cos} \theta_{s}$

where, $P_{\lambda}$ is the TOA reflectance of wavelength $\lambda$ [unit less], $d$ is the earth-sun distance [astronomical units], 

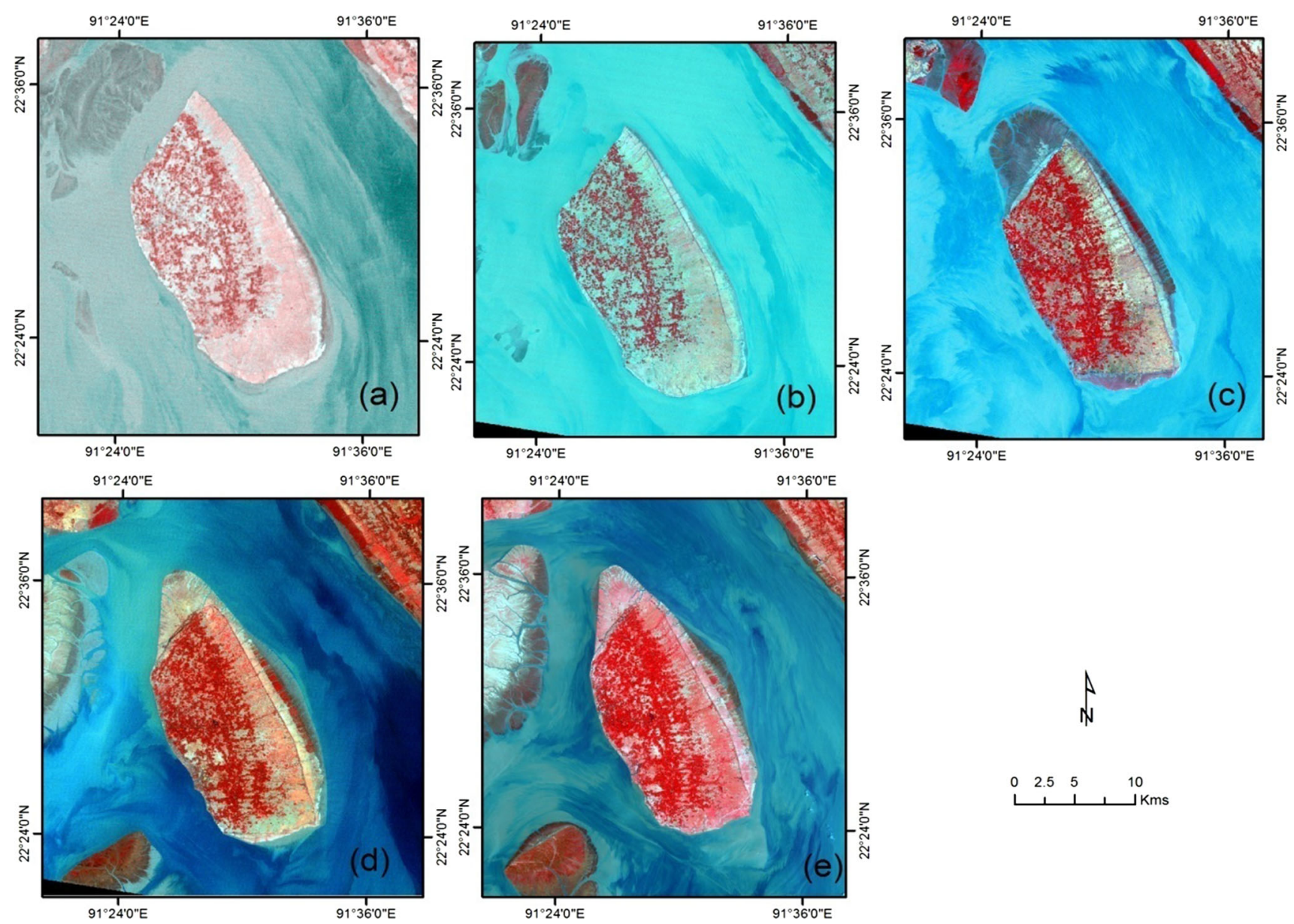

Fig. 2 Satellite imageries (Band 432) of the study area during the period from 1980 to 2014. Landsat MSS image snapshot of (a) February 01, 1980, Landsat TM image of (b) January 05, 1989

and ETM of (c) December 19, 1999 and TM of (d) February 08, 2010 and OLI TIRS of (e) April 24, 2014

Table 1 Satellite imageries used in the study

\begin{tabular}{llllll}
\hline Sensor & Instrument & Acquired date & Path & Row & Local time \\
\hline Landsat 3 & MSS & $1980-02-01$ & 146 & 044 & $09: 34: 41$ \\
Landsat 4 & TM & $1989-01-05$ & 136 & 044 & $09: 50: 52$ \\
Landsat 7 & ETM+ & $1999-12-19$ & 136 & 044 & $10: 11: 34$ \\
Landsat 5 & TM & $2010-02-08$ & 136 & 044 & $10: 09: 31$ \\
Landsat 8 & OLI-TIRS & $2014-04-24$ & 136 & 044 & $10: 18: 30$ \\
\hline
\end{tabular}

$E S U N_{\lambda}$ is mean exo-atmospheric solar irradiance [W/ $\left.\left(\mathrm{m}^{2} \mu \mathrm{m}\right)\right], \theta_{s}$ is the solar zenith angle [degrees], and $L_{\lambda}$ is the spectral radiance at wavelength $\lambda$ at the sensor's aperture $\left[\mathrm{W} /\left(\mathrm{m}^{2} \mathrm{sr} \mu \mathrm{m}\right)\right]$. The $L_{\lambda}$ can be obtained from the DN value also as given by (Chander et al. 2009):

$$
\begin{aligned}
L_{\lambda}= & \left(\left(\operatorname{LMAX}_{\lambda}-\operatorname{LMIN}_{\lambda}\right) /\left(\text { Qcalmax }_{-}-\text {Qcalmin }\right)\right) \\
& *(\text { Qcal }- \text { Qcalmin })+\operatorname{LMIN}_{\lambda}
\end{aligned}
$$

where, $L M A X_{\lambda}$ is the spectral at-sensor radiance scaled to Qcalmax $\left[\mathrm{W} /\left(\mathrm{m}^{2} \mathrm{sr} \mu \mathrm{m}\right)\right], L M I N_{\lambda}$ is spectral at-sensor

radiance scaled to Qcalmin $\left[\mathrm{W} /\left(\mathrm{m}^{2} \mathrm{sr} \mu \mathrm{m}\right)\right]$, Qcalmax is the maximum quantized calibrated pixel value corresponding to $\operatorname{LMAX}_{\lambda}[\mathrm{DN}]$, Qcalmin is the minimum quantized calibrated pixel value corresponding to $L M I N_{\lambda}$ [DN], and Qcal is the quantized calibrated pixel value [DN]. The parameters in the equations can be read from the header files of the MSS, TM, ETM+ and OLI datasets ( $\mathrm{Li}$ et al. 2013). The image data were also processed through a set of preprocessing schedule including a correction for atmospheric scattering (Chavez Jr. 1988) arising from a number of things e.g. shadow, scattering and electrical gain in the sensor. The radiometric correction of the images was carried out using ENVI v5.1.

\section{Water indices}

The McFeeters's NDWI (Mcfeeters 1996) and the Xu's NDWI or MNDWI (Xu 2006) can extract water body information more conveniently than other classification methods. These water indices (NDWIs), calculated from 
various band combinations, can successfully be applied to shoreline change detection studies. However, the McFeeters's NDWI is more efficient for the MSS image whereas the Xu's NDWI or MNDWI is for the TM, ETM+ and OLI satellite image (Li et al. 2013). The McFeeters's NDWI and the Xu's MNDWI, therefore, have been used as the primary tools for shoreline mapping from MSS, TM, $\mathrm{ETM}+$, and OLI remotely sensed images in this study. The equation for an NDWI (McFeeters 1996) for MSS image is:

$$
\mathrm{NDWI}=(\rho \text { Green }-\rho N I R) /(\rho \text { Green }+\rho N I R)
$$

where, $\rho$ Green and $\rho N I R$ are the reflectance of the green and NIR bands respectively. The results from this equation are water features that have positive values whilst soil and terrestrial vegetation have zero or negative values ( $\mathrm{McFe}$ eters 1996). On the other hand, the MNDWI (Xu 2006) for TM and ETM+ image is calculated as:

MNDWI $=(\rho$ Green $-\rho$ MIR $) /(\rho$ Green $+\rho$ MIR $)$

where, $\rho M I R$ refers to the reflection in the mid-infrared band. The MIR band enhances the water signals. However, the Xu's NDWI or MNDWI (Xu 2006) for the OLI satellite image can be obtained as ( $\mathrm{Li}$ et al. 2013):

MNDWI $=(\rho$ Green $-\rho$ SWIR $) /(\rho$ Green $+\rho$ SWIR $)$

where, $\rho S W I R$ is the reflectance in the SWIR band. The Xu's NDWI can enhance open-water features and efficiently suppress and even removes built-up features as well as vegetation and soil features. Therefore, coastal land features can be separated from the water feature employing the NDWI or MNDWIs.

\section{Image threshold segmentation}

The McFeeters's or Xu's NDWIs requires selection of threshold segmentation value which is generally set to zero (Mcfeeters 1996; Xu 2006). However, individual situations need threshold adjustment for more accurate delineation of water bodies (Ji et al. 2009) in the image. Therefore, a dynamic threshold is employed to deal with different areas or different phases of remote sensing data for detecting more precise water body information (Du et al. 2012). The Otsu method which is based on maximum between-class variance is such a dynamic threshold method (Otsu 1979). In this study, the Otsu method was used to determine the threshold to separate water bodies from the background features (non-water).

Using the Otsu method, if it is assumed that the NDWI pixels range from $[\mathrm{x}, \ldots, \mathrm{y}]$, where $-1 \leq x<y \leq 1$, the pixels can be separated into two classes: a non-water class $[x, \ldots, t]$ and a water class $[t, \ldots, \mathrm{y}]$, where $t$ is the threshold value ( $\mathrm{Li}$ et al. 2013). The between-class variance corresponding to the threshold value $(t)$ of the non-water class and water class can be obtained by:
$\sigma^{2}=W_{n w} \sigma_{n w}^{2}+W_{w} \sigma_{w}^{2}$

where, $\sigma$ is the between-class variance of the non-water class and the water class; $\sigma_{n w}^{2}$ is the variance of the nonwater class; $\sigma_{w}^{2}$ is the variance of the water class; $W_{n w}$ is the weighting of the non-water class; and $W_{w}$ is the weighting of the water class. The $W_{x}$ can be calculated from:

$W_{x}=\sum_{x}^{y} P(i)$

where, $P(i)$ is the class probability calculated from the total number of pixels in the image divided by the number of pixels in the class. The Otsu method selects the threshold by using the rule of maximum between-class variance between the background features (e.g. vegetation, soil etc.) and water body features ( $\mathrm{Li}$ et al. 2013) using the Eqs. (1) and (2).

\section{Delineation and measurement}

The classified images were converted from raster to vector format for delineation and measurement purposes using ArcGIS v10.1. Vector data of different years were prepared to measure the shoreline positions and land area of the island. The vector differencing and vector overlay methods were applied to detect the shifting of shoreline position and coastal land areas change (in terms of erosion-accretion) of the island. The changes in shoreline and its rate can be determined by quantifying the amount of shoreline shift along transects with the establishment of a baseline and the shorelines (Chand and Acharya 2010). The rates of shoreline change were measured by using the digital shoreline analysis system (DSAS) extension tool which computes the rate-of-change statistics from multiple historic shoreline positions residing in the GIS environment. The shoreline position for 1980 was considered as the reference baseline position to measure the shifting of the shoreline. The measurement transects were casted from the baseline to intersect all the shoreline positions. The accurate measurement and sampling errors were considered during compiling each shoreline position for better quantification of the statistical reliability of the computed rates (Anders and Byrnes 1991; Crowell et al. 1991; Thieler and Danforth 1994; Moore 2000). The most used statistical methods for the calculation of the shoreline change rates are: the end point rate (EPR) calculations and the net shoreline movement (NSM) (Dolan et al. 1991). The net shoreline movement (NSM) reports the total distance between the oldest and youngest shorelines for each transect. The rate-of-change statistics (EPR) were calculated to measure the shifting rate (m/year) of the shoreline directly of the recent shoreline position through the time. The 
shoreline change rates can be used to extrapolate future changes, if any, in the shorelines (Crowell et al. 1991).

\section{Accuracy assessment}

The accuracy for the classification was conducted through a quantitative assessment in this study. The false-color composite image, for instance, TM, i.e. RGB752 band combination acquired from same raw image data which best enhances the water body information (Du et al. 2012), were used as the reference data to evaluate the accuracy of the classified Landsat image. In addition, most recent ground truth information was collected using a hand carried GPS (spatial accuracy $\pm 5 \mathrm{~m}$ ) through the field visit. The overall accuracy (OA) and the kappa coefficient (Kappa) based on the error matrix (Foody 2002) were employed to evaluate the accuracy of the image classification. The higher OA and kappa value indicate the higher level of accuracy.

\section{Results and discussion}

\section{Shoreline change}

The result shows that the total length of the island's shoreline was about $76.12 \mathrm{~km}$ in 1980 , which has reduced to about $73.04 \mathrm{~km}$ in 2014 (Table 2). The data for changes in the shoreline of the island concludes that the net loss of the shore-length was around $3.07 \mathrm{~km}$ between 1980 and 2014 (Table 3).

The positions of the shorelines for different years are given in the Fig. 3. Four blocks namely A, B, C and D were selected for the detail understanding of the shoreline movement. The net shoreline movement (NSM in $\mathrm{km}$ ) and the end point rate (EPR in $\mathrm{m} /$ year) were measured in these blocks and presented in the Figs. 4 and 5.

Table 2 Shore-length and area of the study area between the year of 1980 and 2014

\begin{tabular}{lrrrrr}
\hline Item/year & 1980 & \multicolumn{1}{c}{1989} & 1999 & \multicolumn{1}{c}{2010} & \multicolumn{1}{c}{2014} \\
\hline Shore-length $(\mathrm{km})$ & 76.11 & 70.43 & 80.49 & 69.13 & 73.04 \\
Area $\left(\mathrm{km}^{2}\right)$ & 248.74 & 228.38 & 242.96 & 225.20 & 210.54 \\
\hline
\end{tabular}

The net shoreline movements (NSM) in the four blocks were calculated as the distance of shoreline movement by the time elapsed between the baseline and the most recent shoreline (Fig. 4). The positive values indicate the accretion i.e. seaward movement while the negative values indicate the erosion i.e. landward movement from the baseline to the most recent shoreline. These amounts of erosion-accretion were measured (in $\mathrm{km}$ ) along the transects. For the block A, the landward movement of baseline is higher, ranging from -1.5 to $-2.3 \mathrm{~km}$, indicating the higher level of erosion (Fig. 4a). The magnitude of erosion is more severe for the block $\mathrm{B}$ since the landward distance from the baseline ranges from -2.1 to $-3.8 \mathrm{~km}$ (Fig. $4 \mathrm{~b}$ ). The block $\mathrm{C}$ represents the seaward movement of the baseline i.e. accretion where the $\mathrm{NSM}$ varies from +0.5 to $+1.6 \mathrm{~km}$ (Fig. $4 \mathrm{c}$ ). However, the block D indicates both seaward and the landward movement of the baseline. The most left portion of the block has experienced erosion (NSM $-0.2 \mathrm{~km}$ ) and the rest of the parts have been undergone accretion (NSM +0.2 to $+2.8 \mathrm{~km}$ ) process (Fig. 4d).

The rate of shoreline shifting was measured in EPR, calculated as dividing the distance of shoreline movement by the time elapsed between the baseline and the most recent shoreline. The positive values indicate the annual rate of accretion and the negative values indicate the annual rate of erosion from the baseline to the most recent shoreline. Higher rate of erosion (EPR $>-100 \mathrm{~m} /$ year) was observed in the most southern periphery of the island (Fig. 5b). The erosion rate with the EPR ranges from -43 to $-68 \mathrm{~m} /$ year were observed along almost the entire eastern banks of the island (Fig. 5a). In contrast, accretion of sediments with different rates was taken place in the western banks with the EPR varies from +13 to $+47 \mathrm{~m} /$ year (Fig. $5 \mathrm{c}$ ) and in the most northern shores (EPR up to $+82 \mathrm{~m} /$ year) of the island (Fig. 5d). However, the rate of inward shifting i.e. erosion exceeds the rate of seaward shifting i.e. accretion which strongly implies the gradual loss of shore towards the island.

\section{Land area change}

In 1980, the total land area of the island was about $248.74 \mathrm{~km}^{2}$ whereas in 2014 it has reduced to $210.54 \mathrm{~km}^{2}$ (Table 2). The amount of erosion and accretion were about 63.66 and $24.82 \mathrm{~km}^{2}$ respectively (Table 3 ). The net loss
Table 3 Changes in shorelength and land area of the island between 1980 and 2014

\begin{tabular}{lccccc}
\hline Type/interval of the year & $1980-1989$ & $1989-1999$ & $1999-2010$ & 2010-2014 & 1980-2014 \\
\hline Shoreline change $(\mathrm{km})$ & -5.68 & 10.07 & -11.37 & -3.91 & -3.07 \\
Common area $\left(\mathrm{km}^{2}\right)$ & 226.10 & 199.32 & 215.12 & 209.28 & 185.84 \\
Erosion $\left(\mathrm{km}^{2}\right)$ & 23.40 & 29.06 & 27.98 & 16.22 & 63.66 \\
Accretion $\left(\mathrm{km}^{2}\right)$ & 2.28 & 43.79 & 10.38 & 1.37 & 24.82 \\
Net loss/gain $\left(\mathrm{km}^{2}\right)$ & -21.12 & 14.73 & -17.60 & -14.85 & -38.84 \\
\hline
\end{tabular}




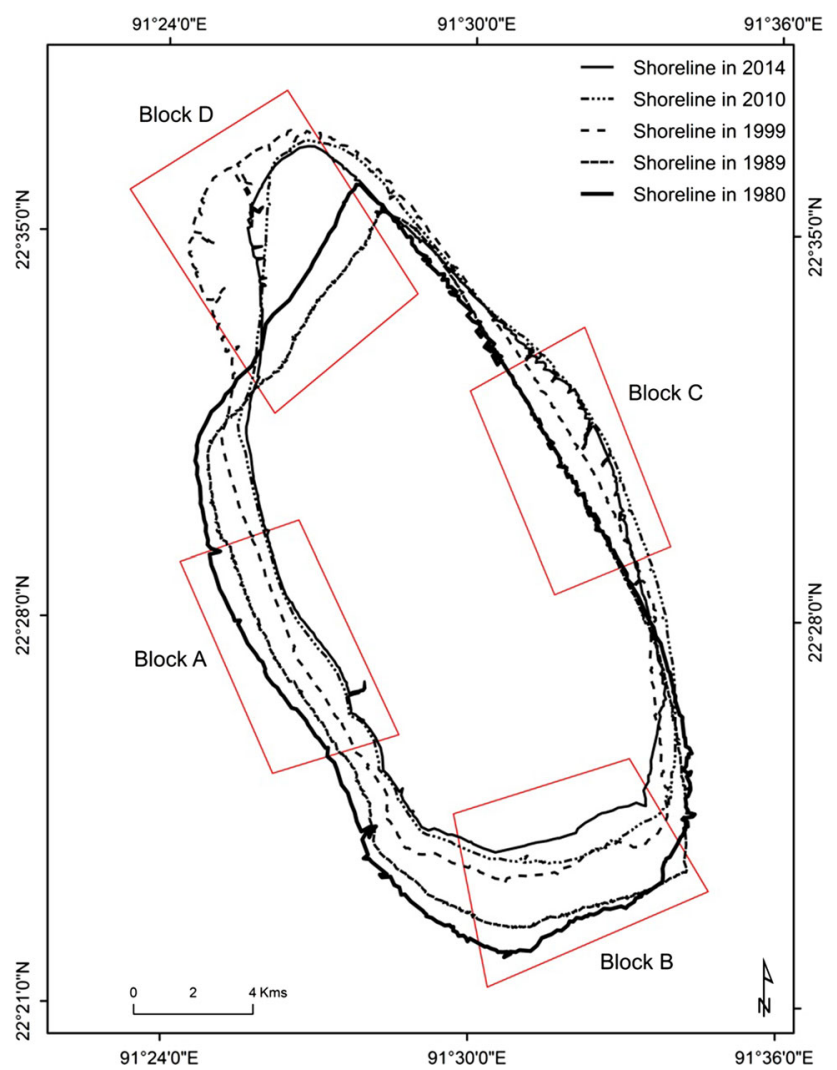

Fig. 3 Shorelines position of the study area between 1980 and 2014. The boxes represent four blocks namely $A, B, C$, and $D$ in different portions of the island

of land area was, therefore, about $38.84 \mathrm{~km}^{2}$ between these times (Table 3).

The erosion processes were active in the northern, western and the south-western part of the island from 1980 to 1989 (Fig. 6a). However, accretion within this time span was effective in some parts of the north-eastern and southwestern parts of the island by the sediment deposition carried from the channel. The erosion processes were more effectively severe than the accretion which resulted net loss of about $21.11 \mathrm{~km}^{2}$ land area to erode (Table 3). From the period 1989 to 1999 , erosion processes were mainly active in the western, south-western and some of the southwestern parts of the island (Fig. 6b). Within this time span, accretion has been taken place in large parts of the northern and some of the south-eastern parts of the island due to land reclamation. The island gained maximum sediment deposition which formed a new island (char) in the northern part. It results the net gain of $14.73 \mathrm{~km}^{2}$ land between this times (Table 3 ). The erosion processes were active in the northern, western and southern part of the island between 1999 and 2010 (Fig. 6c). The char lands that had been evolved in the northern part in previous years (1989-1999) have gone under the severe erosion in this time period. Therefore, it results the net loss of about $17.60 \mathrm{~km}^{2}$ land area to erode (Table 3). However, accretion was effective in some part of the eastern and the southeastern part of the island during that period. The Fig. 6d indicates the presence of erosion processes in the northeastern, southern and south-western part of the island between 2010 and 2014. Within this time span accretion was effective in the small of the north-western part of the island. The island has lost about $14.85 \mathrm{~km}^{2}$ area land between these years (Table 3). The final composite result of the last 34 years (1980-2014) data concludes that severe erosion processes were active in the western (Kalapani, Harispur, Rahmatpur, Azimpur, and some part of the Santoshpur Union ${ }^{5}$ ), the south-western (Sarikait Union) and some of the southern (Maghara Union) parts of the island (Fig. 6e). In contrast, accretion was effective in the large part of the northern (Santoshpur Union, Urir char) and the north-eastern (Maghara Union) part of the island. Between 1980 and 2014, the island has gained about $24.82 \mathrm{~km}^{2}$ or $0.75 \mathrm{~km}^{2} /$ year land areas (Table 3) due to sediment deposition or through the formation of new islands (char). On the other hand, it has lost about $63.65 \mathrm{~km}^{2}$ or $1.87 \mathrm{~km}^{2} /$ year land area (Table 3). Therefore, the changes of land areas for the island is inclined to the loosing phase with a considerable amount of lands have been being eroded day by day. The net loss of land, due to predominance of erosion process over the accretion, was about $38.84 \mathrm{~km}^{2}$ or $1.1 \mathrm{~km}^{2} /$ year lands to be disappeared ever (Table 3).

\section{Result of accuracy assessment}

The accuracy assessments of image classification were done with the reference data, taken at the same time of the image used in the study to minimize any time-dependent effects ( $\mathrm{Li}$ et al. 2013). The overall accuracy (OA) and kappa-co-efficient were carried out to quantitatively asses the classified images. The error matrixes were created first to obtain OA and Kappa statistics in GIS environment. The values of the overall accuracy (OA) of classified maps for the year of 1980, 1989, 1999, 2010, and 2014 were, respectively, $98.5,99.5,97.0,96.5$, and $98.5 \%$, while the kappa-co-efficient were $0.92,0.99,0.94,0.93$ and 0.97 respectively (Table 4). The higher values of OA and Kappa for the study certify the efficiency of classification accuracy.

\footnotetext{
${ }^{5}$ A small administrative sub-unit.
}

$\overline{4}$ The Bengali meaning of island(s). 

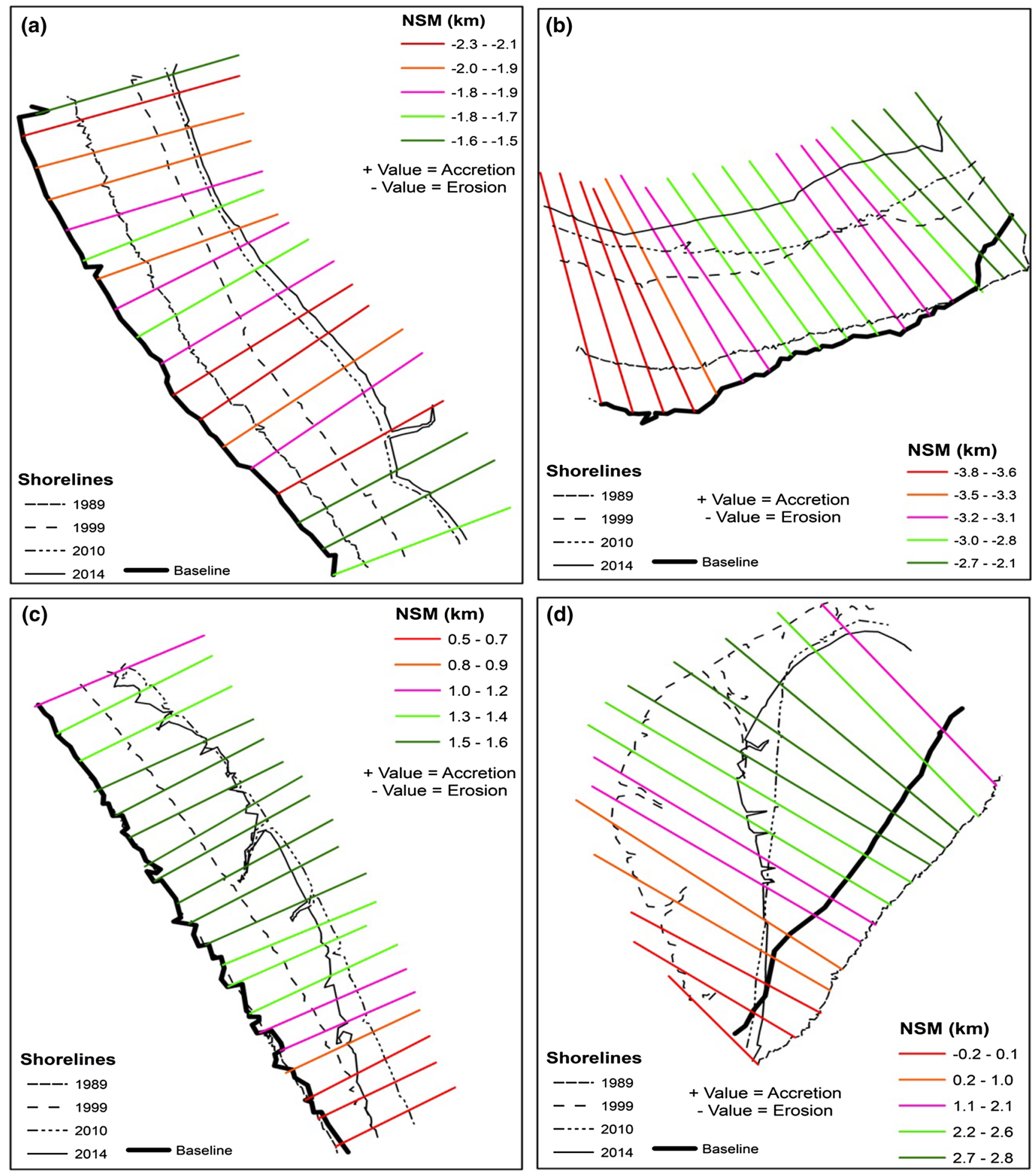

Fig. 4 Net shoreline movement (NSM in $\mathrm{km}$ ) for the block a A, b B, c C and d D

\section{Conclusion}

The island has lost its coastal shoreline and areas since last 34 years. Only between the year of 1989 and 1999, the island has gained maximum accretion of $43.79 \mathrm{~km}^{2}$ area.
In 1980, the total land area of the island was $248.74 \mathrm{~km}^{2}$ whereas in 2014 it has reduced to $210.54 \mathrm{~km}^{2}$. The island has lost its shore-length of $3.07 \mathrm{~km}$. The amount erosion and accretion were about $63.66 \mathrm{~km}^{2}$ or $1.87 \mathrm{~km}^{2} /$ year and $24.82 \mathrm{~km}^{2}$ or $0.75 \mathrm{~km}^{2} /$ year respectively. The distance and 

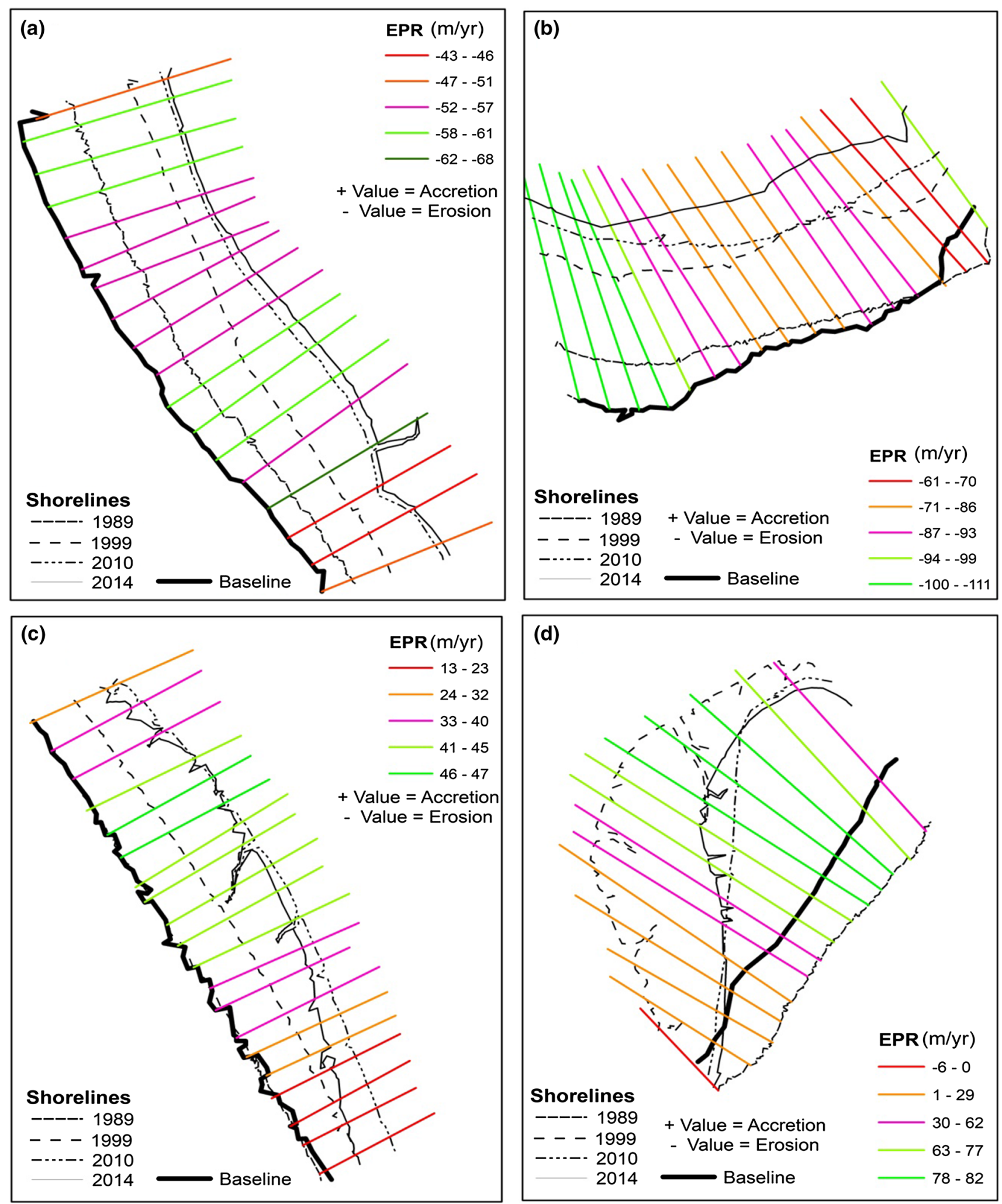

Fig. 5 Rate of shoreline movement (EPR in m/year) for the block a A, b B, c C and d D 
Fig. 6 Erosion-accretion in study area between the year a $1980-1989$, b 1989-1999, c 1999-2010, d 2010-2014, and e 1980-2014

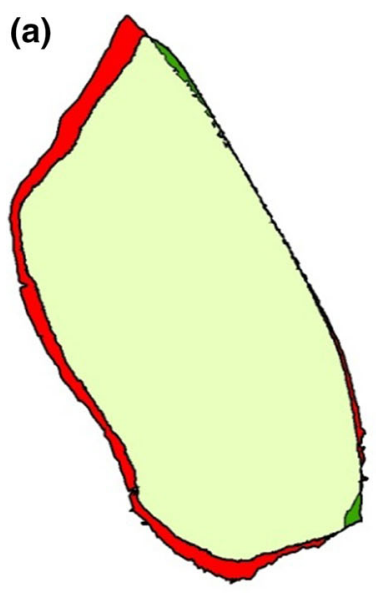

(b)

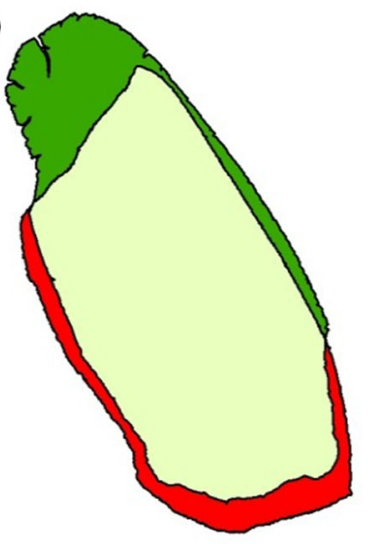

(d)

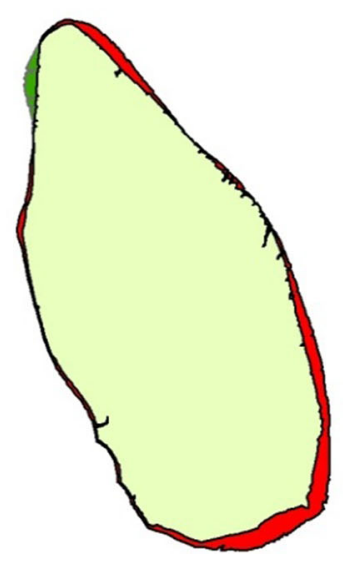

Table 4 Overall accuracy (OA) and kappa co-efficient for the classification

\begin{tabular}{lccccc}
\hline Item/year & 1980 & 1989 & 1999 & 2010 & 2014 \\
\hline Overall accuracy & $98.5 \%$ & $99.5 \%$ & $97.0 \%$ & $96.5 \%$ & $98.5 \%$ \\
Kappa co-efficient & 0.92 & 0.99 & 0.94 & 0.92 & 0.97 \\
\hline
\end{tabular}

rate of shoreline movement both are higher in western and most southern banks whereas lower in the other parts of the island. The erosions were taken palace mostly in more exposed part of the island combining with tidal water pressure, shoreline configuration, loose bank materials and steep slope- leads to erosion. The accretion was active in relatively gentle sloppy banks due to backwash sediment deposition.

\section{References}

Alam M (2003) Bangladesh Country Case Study. National Adaptation Programme of Action (NAPA) Workshop, 9-11 September 2003, Bhutan (c)

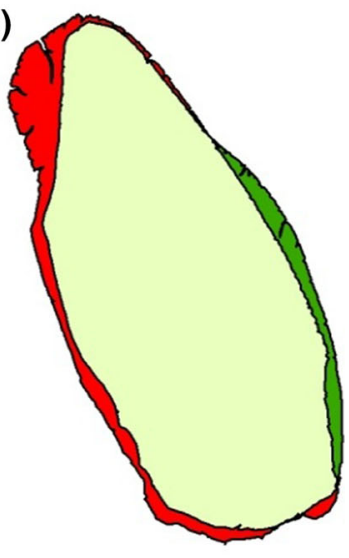

(e)

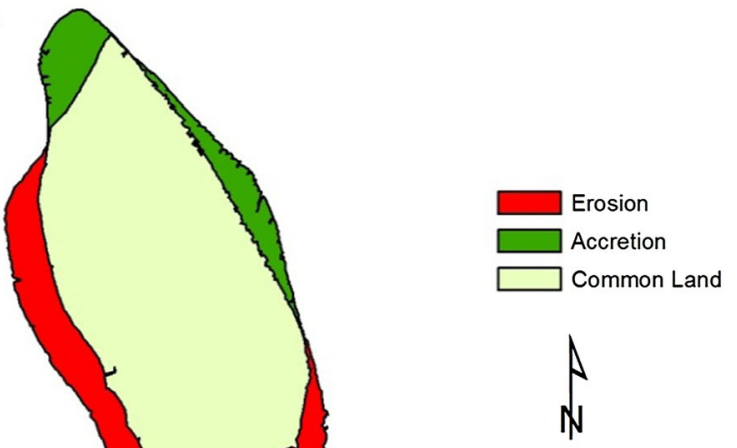

Ali A (2000) Vulnerability of Bangladesh coastal region to climate change with adaptation option. Bangladesh Space Research and Remote Sensing Organization (SPARRSO), Dhaka

Anders FJ, Byrnes MR (1991) Accuracy of shoreline change rates as determined from maps and aerial photo-graphs. Shore Beach 59:17-26

BBS (2014) Community Report of Chittagong Zila, Population and Housing Census 2011. Bangladesh Bureau of Statistics, Ministry of Planning, Government of the People's Republic of Bangladesh

Behera MD, Chitale VS, Shaw A, Roy PS, Murthy MSR (2012) Wetland monitoring, serving as an index of land use change-a study in samaspur wetlands, Uttar Pradesh, India. J Indian Soc Remote Sens 40:287-297

Bortels L, Chan JCW, Merken R, Koedam N (2011) Long-term monitoring of wetlands along the western-greek bird migration route using landsat and ASTER satellite images: Amvrakikos Gulf (Greece). J Nat Conserv 19:215-223

Bouchahma B, Yan W (2012) Automatic measurement of shoreline change on Djerba Island of Tunisia. J Comput Inf Sci, vol 5(5)

Brammer H (2014) Bangladesh's dynamic coastal regions and sealevel rise. Elsevier J Clim Risk Manag, pp 51-62

Brammer H, Asaduzzaman M, Sultana P (1993) Effects of climate and sea-level changes on the natural resources of Bangladesh, Briefing Document No. 3. Bangladesh Unnayan Parishad (BUP), Dhaka

Brunn P (1962) Sea level rise as a cause of shore erosion. J Waterw Harb Div 88(117):130 
Chand P, Acharya P (2010) Shoreline change and sea level rise along coast of Bhitarkanika wildlife sanctuary, Orissa: an analytical approach of remote sensing and statistical techniques. Int $\mathbf{J}$ Geomat Geosci 1(3):436-455

Chander G, Markham BL, Helde DL (2009) Summary of current radiometric calibration coefficients for landsat MSS, TM, ETM+, and EO-1 ALI sensors. Remote Sens Environ 113:893-903

Chavez PS Jr (1988) An improved dark-object subtraction technique for atmospheric scattering correction of multispectral data. Remote Sens Environ 24(3):459-479

Crowell M, Leatherman SP, Buckley MK (1991) Historical shoreline change-error analysis and mapping accuracy. J Coast Res $7: 839-852$

Dasgupta S, Laplante B, Meisner C, Wheeler D, Yan J (2009) The impact of sea level rise on developing countries: a comparative analysis. Clim Change 93:379-388

Dean RG (1977) Equilibrium beach profiles: US Atlantic and Gulf coasts. Newark Department of Civil Engineering Report 12, University of Delaware

Dolan R, Fenster MS, Holme SJ (1991) Temporal analysis of shoreline recession and accretion. J Coast Res 7(3):723-744

Du Z, Linghu B, Ling F, Li W, Tian W, Wang H, Gui Y, Sun B, Zhang X (2012) Estimating surface water area changes using time-series landsat data in the Qingjiang river basin, China. J Appl Remote Sens 6:063609

El-Asmar HM, Hereher ME (2010) Change detection of the coastal zone east of the Nile delta using remote sensing. J Environ Earth Sci. doi:10.1007/s12665-010-0564-9

Everts C (1985) Sea-level rise effects on shoreline position. J Waterw Ports Coast Ocean Eng Div 111:985-999

Foody GM (2002) Status of land cover classification accuracy assessment. Remote Sens Environ 80:185-201

Healy T (1991) Coastal erosion and sea level rise. Zeitschrift für Geomorphologie Supplementbandt 81:15-29

Ji L, Zhang L, Wylie B (2009) Analysis of dynamic thresholds for the normalized difference water index. Photogram Eng Remote Sens 75:1307-1317

Karsli F, Guneroglu A, Dihkan M (2011) Spatio-temporal shoreline changes along the southern black sea coastal zone. J Appl Remote Sens 5:053545

Kont A, Ratas U, Puurmann E (1997) Sea-level rise impact on coastal areas of Estonia. Clim Change 36:175-184

Li W, Zhiqiang D, Feng L, Dongbo Z, Hailei W, Yuanmiao G, Bingyu S, Xiaoming Z (2013) A comparison of land surface water mapping using the normalized difference water index from TM, ETM+ and ALI. Remote Sens 5:5530-5549

Mcfeeters SK (1996) The use of the normalized difference water index (ndwi) in the delineation of open water features. Int $\mathbf{J}$ Remote Sens 17:1425-1432

McGranahan G, Balk D, Anderson B (2007) The rising tide: assessing the risk of climate change and human settlements in low elevation coastal zones. Environ Urban 19:17-37

Moore LJ (2000) Shoreline mapping techniques. J Coast Res $16: 111-124$
Mukhopadhyay A, Mukherjee S, Hazra S, Mitra D (2011) Sea level rise and shoreline changes: a geoinformatic appraisal of Chandipur coast, Orissa. Int J Geol Earth Environ Sci 1(1):9-17

Nicholls RJ, Hoozemans FMJ, Marchand M (1999) Increasing flood risk and wetland losses due to global sea-level rise: regional and global analyses. Glob Environ Change 9:S69-S87

Nicholls RJ, Wong PP, Burkett VR, Codignotto JO, Hay JE, McLean RF, Ragoonaden S, Woodroffe CD (2007) Coastal systems and low-lying areas. In: Parry ML, Canziani OF, Palutikof JP, van den Linden PJ, Hanson CE (eds) Climate change, impacts, adaptation and vulnerability. Contributions of Working Group II to the Fourth assessment report of the intergovernmental panel on climate change, Cambridge University Press, Cambridge, pp 315-356

Otsu N (1979) A threshold selection method from gray-level histograms. IEEE Trans Syst Man Cybern 9:62-69

Pramanik MAH (1988) Methodologies and techniques of studying coastal systems. SPARRSO case studies, Presented at the national development and management, held in Dhaka, Bangladesh, 3-4 Oct 1988

Rob MA (1997) Shifting course of the Ganges in Bangladesh: a study in fluvial morphology. Dhaka Univ J Sci 45(2) (printed version)

Sarwar MGM (2005) Impacts of sea level rise on the coastal zone of Bangladesh. Unpublished MS thesis, Lund University, Sweden

SDNP (2004) Climate Change \& Bangladesh: sea level rise, Bulletin published on World Environment Day, 05 June 2004, Sustainable Development Networking Programme (SDNP), Dhaka, Bangladesh. http://www.bdix.net/sdnbd_org/world_env_day/ 2004/

Sharmin S (2013) Climate change and its effect on coastal area of Bangladesh. Asian J Sci Technol 4(12):015-020

Thieler ER, Danforth WW (1994) Historical shore-line mappingimproving techniques and reducing positioning errors. J Coast Res 10:549-563

Tirkey N, Biradar RS, Pikle M, Charatkar S (2005) A study on shoreline changes of mumbai coast using remote sensing and GIS. J Indian Soc Remote Sens 33:8591

UNEP (1989) Retrieved on June, 2014 from the website (http://www. grida.no)

Wang X-Z, Zhang H-G, Fu B, Shi A (2013) Analysis on the coastline change and erosion-accretion evolution of the Pearl River estuary, China, based on remote-sensing images and nautical charts. J Appl Remote Sens 7(1):073519. doi:10.1117/1.JRS.7. 073519

World Bank (2000) Bangladesh: climate change \& sustainable development. Report No. 21104 BD, Dhaka

$\mathrm{Xu} \mathrm{H}$ (2006) Modification of normalized difference water index (NDWI) to enhance open water features in remotely sensed imagery. Int J Remote Sens 27:3025-3033

Yanli T (2011) The application of GIS and RS for coastline change detection and risk assessment to enhanced sea level rise. International Institute for Geoinformation Science and Earth Observation, Netherlands 